\title{
Heterogeneity versus Homogeneity in Schools: A Study of the Educational Value of Classroom Interaction
}

\author{
Daniel Gabaldón-Estevan \\ Department of Sociology and Social Anthropology, Faculty of Social Sciences, University of Valencia, \\ 46021 València, Spain; Daniel.Gabaldon@uv.es
}

Received: 30 September 2020; Accepted: 12 November 2020; Published: 18 November 2020

\begin{abstract}
The degree of homogeneity and heterogeneity among schools affects the comprehensiveness and inclusiveness of the school system and the type and scope of classroom interaction. Since the beginning of the 1980s, interest has gradually increased in the effects of homogeneity and heterogeneity of schools on classroom interactions; this research involves various disciplines and has different goals. The present paper contributes to academic debate on the often ignored consequences of socialisation of pupils with diversity. In particular, we revise the evidence on the effect of socialisation (or lack of it) with diversity resulting from the degree of homogeneity or heterogeneity to which school children are exposed through their interactions in the classroom. We aim, in particular, to shed light on what the assumed value of classroom interactions as an argument in favour or either heterogeneous or homogeneous groups. We review work analysing school homogeneity in relation to age, gender, ethnicity and disability and the effect on classroom interactions. Most studies concur with current achievement motivation theories, which highlight the important role of context and agents of socialisation, such as classroom peers, in the development of pupils' beliefs and behaviours. Studies that find support for classroom homogeneity tend to focus narrowly on academic performance, whereas findings that support classroom heterogeneity tend to analyse higher order values such as equity and inclusiveness. The findings in the literature suggest, furthermore, that children's experiences of exclusion and diversity influence their friendship decision-making, suggesting that heterogeneous schools promote a more inclusive society.
\end{abstract}

Keywords: school segregation; socialisation; child development; institutionalisation; social integration

\section{Introduction}

Classroom interaction is considered important for the socialisation of new generations in modern societies [1]. Socialisation refers to the process of interiorising beliefs, norms and social values, of learning to be part of society and to perform our role in it [2]. The institutions of both family and school, interact throughout a child's development, and are dominant at different moments of a child's development [3]. Family functions, fundamentally, to ensure that the child survives, remains health, grows and is socialised with the basic behaviours of communication, dialogue and symbolisation, as required to meet the needs of early childhood [4,5]. The diffusion of early and pre-schooling has increased the relevance of education for socialising children [6]. Early childhood education works to support the family and stimulate pre-school age children to enable them to relate to their physical and social environment and respond to the demands made by their environment [7].

Thus, school is not just the place where academic knowledge is transmitted, it is also the where the child learns to socialise with non-family members. Dreeben points out that "schools and classrooms have a characteristic pattern of organisational properties different from those of other agencies in 
which socialisation takes place and on the contention that what children learn derives as much from the nature of their experiences in the school setting as from what they are taught" [8] (p. 211).

As the child ages, school becomes more relevant through:

"the influence exercised by adult generations on those that are not ready for social life. Its object is to arouse and to develop in the child a certain number of physical, intellectual, and moral states that are demanded of him by the political society as a whole and by the special milieu for which he is specifically destined. To the egotistic and asocial being that has just been born, [society] must as rapidly as possible add another capable of leading a moral and social life". [9] (p. 148)

The classroom has been described as: "a vital and psychological space where a group of individuals with different experiences, background knowledge and expectations live together ( ... ) The aim is to reinterpret the new educational challenges of the current society of knowledge and information with a view to rediscovering a new knowledge with no social exclusion" [10] (p. 444).

However, research shows that, depending on how children are grouped, for example, by age, gender, social class, disability or racial or ethnic background, they will have different experiences [11] (p. 29). Among the factors that affect students' socialisation, the degree of school homogeneity or heterogeneity emerges as very relevant, since it determines the degree of diversity related to classroom interactions. There are some notable differences among schools in terms of the heterogeneity of the student body [8]. In more diverse societies, high levels of school homogeneity tend to be linked to school segregation, ghetto schooling or even no schooling.

The concept of equity in the education was introduced during an Organisation for Economic Co-operation and Development (OECD) conference held in Sweden in 1961 and was developed by Levin [12] in a study for the OECD. Levin distinguishes between two dimensions of equity in education. The first is fairness, which implies ensuring that personal traits and social circumstances, such as gender, ethnic origin or social class, do not prevent the student from achieving his or her educational potential. The second is inclusion, which implies that a minimum basic standard of education must be guaranteed for all children [13].

The question of school inequality is addressed differently across Europe. It has been shown [14] that, although both "no-choice" with "no-tracking" and "choice" with "tracking" and "school variability" resulted in efficient school systems, only "no-choice" with "no-tracking" led to greater equity. The right to education is based on education equity, which is highly valued and recognised internationally such as the Council of Europe Commissioner for Human Rights:

"The right to education is a fundamental human right. Yet, many European countries still deny thousands of children, including children with disabilities, Roma children and refugee or migrant children, equal access to it by keeping them in segregated schools. This is a violation of children's human rights with far-reaching negative consequences for our societies. Member states have an obligation to secure the right of every child to quality education without discrimination". [15]

According to the World Bank, Hungary, Romania, Slovakia, Belgium and Spain are the five European countries where economically poor students most often find themselves in a school that has other similarly economically poor students, leading to worse school performance [16] (p. 28).

In Spain, the school system is atypical within the European Union and involves one in three students being enrolled in a private, but publicly subsidised school. Private education is more dominant at pre-compulsory school age (especially up to 2 years $[17,18]$ and in industrialised regions such as Madrid, Catalonia and the Basque country. This triple system of public schools (charter subsidised schools and private non-subsidised schools) promotes competition and fosters homogeneity in students social class, ethnicity [19] and, also, gender. This inequity in the Spanish education system has been recognised [20]. However, segregation occurs worldwide [21]; it hinders the social mobility of pupils 
and families and contributes to reproducing social divides and family differences and reduces the chances of an equitable and good quality education [22,23].

Some research that compares school homogeneity with heterogeneity suggests that school segregation is linked to differential access to educational resources. Other studies focus on how this differential access affects academic performance. However, few studies examine how school segregation, through its effect on classroom diversity, affects the process of socialisation through classroom interaction at both the student-student and teacher-student levels. In this paper, we review the scientific literature on the effect on classroom interaction of school homogeneity versus school heterogeneity. We try to shed light on the assumed value of classroom interactions and their relation to heterogeneous or homogeneous grouping. We address the following questions: How much attention from the scientific community has this topic attracted? Is there more of a focus on particular aspects of segregation (i.e., attainment, age, gender, ethnicity, social class or disability)? Is there a consensus on the value of homogeneous versus heterogeneous groups? Section 2 describes the methodology employed in this paper. Section 3 presents the results for types of inequality. Section 4 concludes with a discussion of the findings.

\section{Materials and Methods}

We analysed a sample of scientific publications obtained from the Web of Science (WOS) and Scopus databases. We categorise them according to discipline and topic to show how interest in the topic has evolved over time.

Our objective is to measure the impact of, or trends related to, a particular piece of terminology, by conducting comparative analyses of the works included in these international multidisciplinary databases [24]. However, the articles derived from Google Scholar are not all linked to peer-reviewed scientific journals. We therefore restricted our sample to articles derived from WOS and Scopus.

Our search of the WOS and Scopus databases was performed during August 2020, using the search terms presented in Table 1. Our sample selections were based on their occurrence in the article title, the article abstract and/or the article keywords. We did not impose a specific time period. We paid particular attention to the relation between a specific research field and school homogeneity or heterogeneity and classroom interaction.

Table 1. Search terms and number of articles derived from each database.

\begin{tabular}{cccc}
\hline Search Terms & WOS & Scopus & Total \\
\hline "school homogeneity" AND “classroom interactions" & 10 & 5 & 12 \\
"school heterogeneity" AND “classroom interactions" & 23 & 23 & 34 \\
Total & 32 & 25 & 42 \\
\hline
\end{tabular}

Source: Own elaboration. Note: the totals do not include duplicates.

Table 1 shows that the search was conducted in English using the search terms "school homogeneity" AND "classroom interactions" and "school heterogeneity" AND "classroom interactions", applied to the WOS and Scopus databases. We conducted manual cleaning to purge the sample of duplicates, irrelevant publications, papers in languages other than English or Spanish, and documents unrelated to the topic of this study. We included seven additional relevant works identified by the author as part of some previous research. Figure 1 shows the PRISMA 2009 flow diagram [25]. 


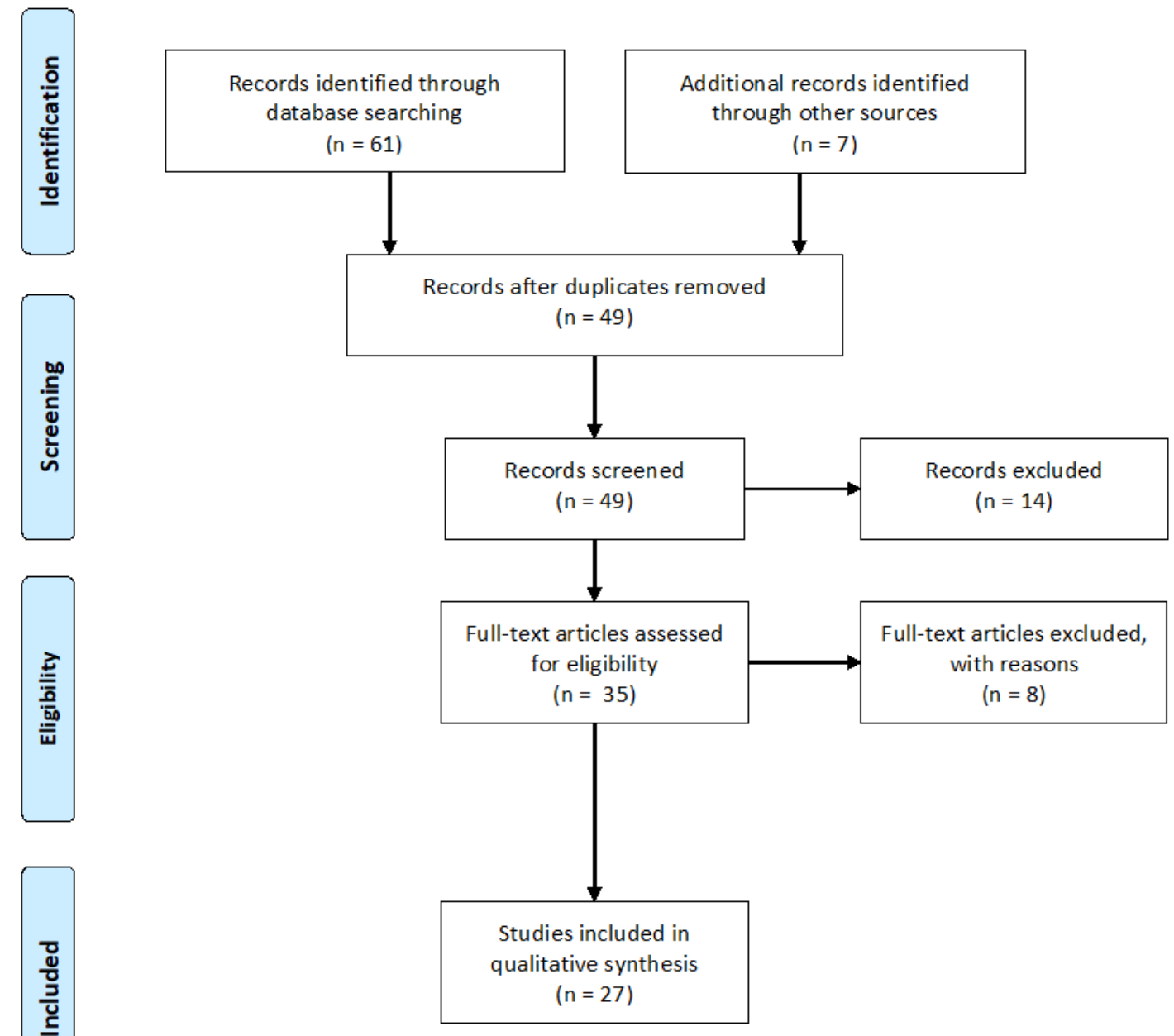

Figure 1. PRISMA 2009 Flow Diagram. Adapted from [25].

We conducted content analysis of the articles to identify the topics covered. We read all the articles and then clustered them within ad hoc categories, including gender, age and ethnicity, which were the most frequent categories. Very few papers focused on disability and age. Our results refer to the categories identified.

\section{Results}

We conducted a quantitative overview of trends followed by a qualitative analysis of the selected papers.

The quantitative analysis shows that the topic has attracted more scholarly attention in recent years. While the first publication is dated 1977, among the 27 publications in the sample, 14 were published between 2012 and 2020. This can be seen in the graph in Figure 2.

Figure 3 shows the annual distribution of the 28 papers ( 27 plus one, counted twice because it deals both with age and gender) and the specific subtopic. The most frequent topics are related to pedagogy and what we call "ethnicity and teachers". Pedagogy includes pedagogical approaches to dealing with and benefitting from diversity. Almost one in three papers $(28.57 \%)$ focuses on one of these topics. Our ethnicity and teachers category refers to papers focusing on both of these aspects. The third most frequent subtopic is homogeneity versus heterogeneity: this accounts for $25 \%$ of the articles. The fourth and fifth more frequent categories refer to gender (three publications or $10.71 \%$ of the total) and disability (two publications or $7.14 \%$ of the total). The sixth category is age (one paper or $3.57 \%$ of the total). The first and third most frequent subtopics, pedagogy and homogeneity versus 
heterogeneity are fairly evenly spread across the whole period whereas ethnicity and teachers occurs mostly since 2010. In the case of the other three subtopics, their scarceness does not allow for the identification of a trend.

In what follows, we discuss the papers in these six categories in relation to the classroom homogeneity versus heterogeneity and classroom interaction debate.

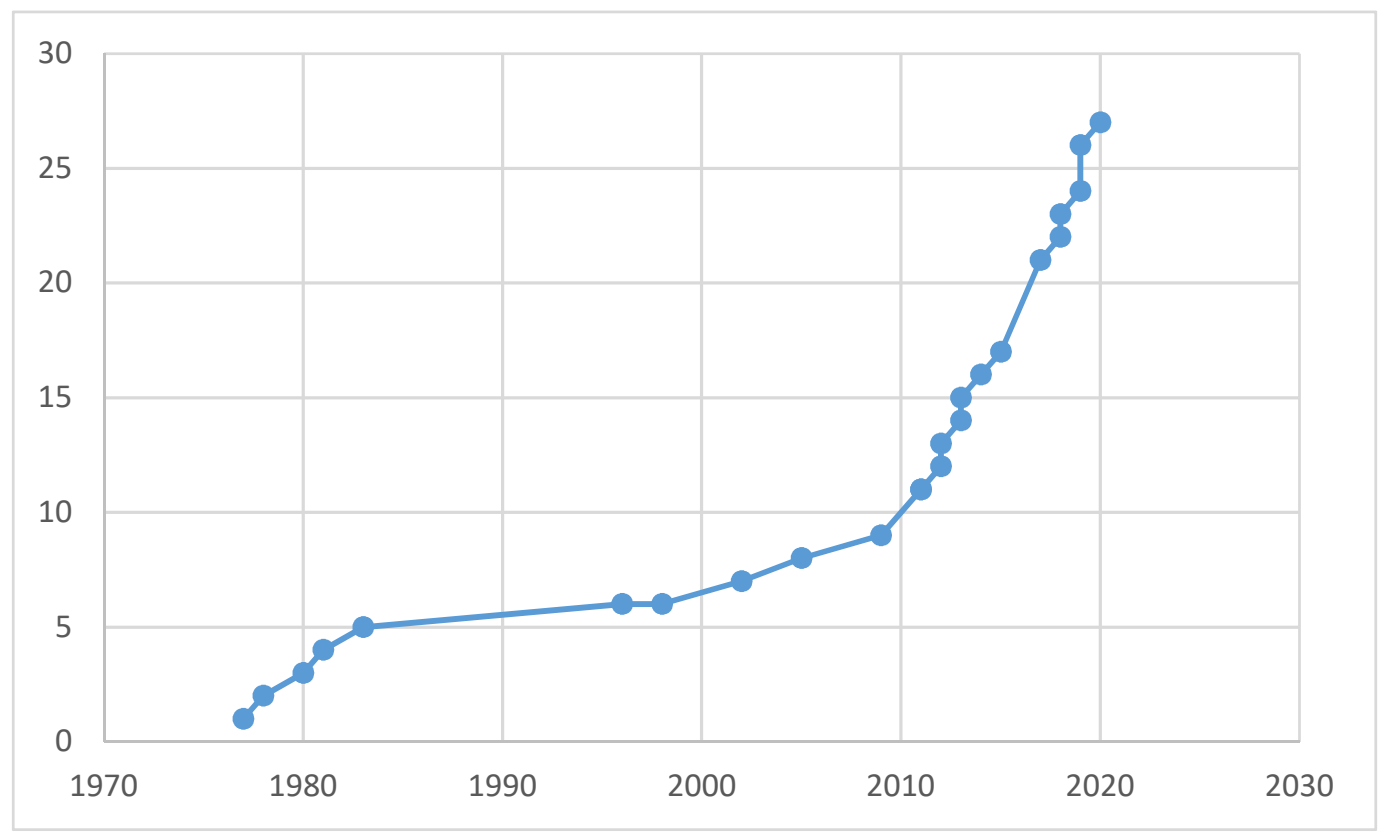

Figure 2. Cumulative frequency of publications (up to August 2020). Source: Own elaboration.

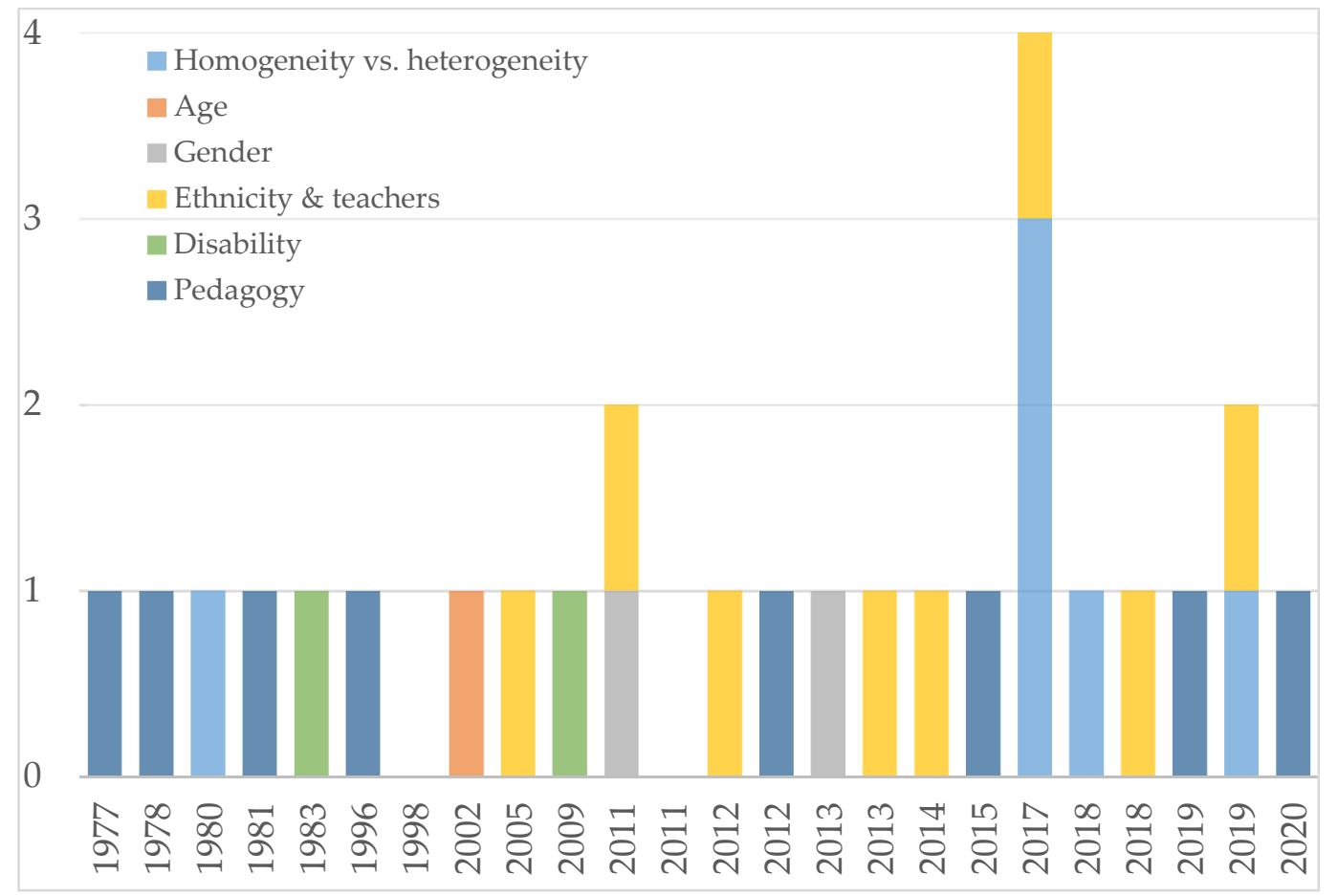

Figure 3. Distribution of publications by topic and year of publication. Source: Own elaboration. 


\subsection{Pedagogy}

The most important papers [26-28] focused on the effectiveness of learning based on different learning goals and pedagogical strategies. For instance, Johnson and colleagues [26] studied the effects of the perspective taking and egocentrism related to problem solving in heterogeneous and homogeneous group interactions. It seems that perspective-taking affects creative solutions, characterised by collaboration and effective communication, and greater trust, attraction, and work satisfaction among group members. However, there seem to be no differences between heterogeneous and homogeneous groups of nurse students in North America. In a study of advanced fifth and sixth grade white math students in a suburban, upper-middle-class US school, cooperative learning promoted a more positive attitude to heterogeneity among peers, higher levels of self-esteem, a more positive attitude towards the teacher, fellow students and conflict, a stronger internal locus of control and a higher level of achievement compared to individual learning [27]. A meta-analysis of 122 studies conducted in 1981 focused on achievement and productivity and found that cooperation was more effective than interpersonal competition and individual efforts and that cooperation with intergroup competition was superior to interpersonal competition and individual efforts, and found no significant differences between interpersonal competitive and individual efforts [28].

The study by Waldripl et al. [29] proposes a tool to assess the culturally sensitive learning environment in schools in North America where the diversity of their scope and clientele had increased. The findings suggest that teachers should try to match their teaching strategies to students' cultural expectations: "In practice, this would mean that the teacher, acting in the role of a school-based manager of learning, can select a balanced set of strategies and instructional approaches appropriate to the profile that has been determined by the teacher" [29] (p. 197).

The studies by Peralta et al. [30-33] focus on pedagogical approaches to dealing with and benefitting from diversity. The work by Peralta et al. [30] concludes that socio-cognitive conflict is an important strategy for achieving more equal participation and homogeneity in the learning process and greater respect for the opinions of peers. Kärner et al. [31] examine heterogeneity in the prior knowledge of vocational students in Germany, focusing on domain-specific prior knowledge. This study suggests that prior knowledge is not a prerequisite for effective classroom dialogue, but is decisive for participation and involvement in interactions related to cognitive elaboration. In their study, Barrio-Parra et al. [32] found that in the context of first year university (or freshman) courses, collaborative learning produces synergies that contribute to the learning process. Collaborative learning is seen as a way of considering heterogeneity not as problem, but as an opportunity for achieving equality among students. The work by Chen et al. [33], focuses on kindergarten pupils and finds that "circle" time is important for promoting inclusivity. Based on Bernstein's communication model, egalitarian relationships reduce control and power. Circle time, by emphasising democracy, egalitarianism, inclusiveness, tolerance and solidarity, characterises the basic features of a modern European education.

In sum, the studies in this category consider heterogeneity to be typical of modern societies and schools and beneficial for students' learning and socialisation.

\subsection{Ethnicity and Teachers}

Articles dealing with ethnicity-related classroom interactions tend to focus either on the role of the teacher [34-39] or the effect of peer group composition [40,41]. In the first case an analysis of school social cohesion in the Netherlands, which ranges from high (pro-social interactions) to low (antisocial or violent interactions), found that secondary school teachers' attitudes varied according to the ethnic composition of the class [34]. The author found that young, female teachers and teachers working either in schools with poor academic results or in low-attainment educational settings, were applying more curricular differentiation and collaborated more with pupils on disciplinary matters than their counterparts. The work by Riegel [35] discusses teachers' attitudes to social differences and social heterogeneity reflected in their pedagogy. Their work highlights the ambivalence and the problems 
related to othering and discrimination. The paper by García-Sánchez [36] analyses cultural citizenship as the product of everyday educational discourse and classroom interaction, in the context of a rural school in Spain with a high percentage of Moroccan immigrant children. It finds that:

"teachers' intended goal in class discussions is to foster interculturality, inclusion and class participation of immigrant and minority children, these practices, as realized in actual student-teacher interactions, may have the unintended, paradoxical consequence of further marking Moroccan immigrant children's as 'Other', and of symbolically upholding ideals of a homogeneous imagined national community $(\ldots$ ) of which the immigrant children in the class cannot be part. teachers, inadvertently and ironically, take part in excluding immigrant children from belonging to the national collectivity, by engaging in practices of distinction, authentication, and authorization through everyday linguistic and interactional practices, such as deixis, appellation, and forms of class participation". [36] (p. 491)

Yates et al. [37] identified teacher bias in an analysis of children's pretend play in a laboratory and a school setting. They found that teachers ascribe different meanings to children's behaviour based on their race: 'among Black preschoolers, imaginative and expressive pretend play features were associated with teachers' ratings of less school preparedness, less peer acceptance, and more teacher-child conflict, whereas comparable levels of imagination and affect in pretend play were related to positive ratings on these same measures for non-Black children" [37] (p. 1).

They suggest that the: "findings raise significant concerns about if and how early bias may portend long-term differences in children's imagination, expressiveness, and/or adjustment as a function of their classroom experiences ( ... ) we must take necessary steps to mitigate the expression of unconscious, socially structured beliefs and expectations in our classrooms" [37] (p. 9)

Penney [38] provide evidence that students who are of the same race as the teacher tend to perform better academically and suggest that early exposure to a teacher of the same race provides benefits that persist in the medium term, believing that this contributes to explaining the black-white test score gap. Muñoz-Hurtado [39] examine the extent to which teachers should be concerned about students' peer group relations and conclude that they should be cognisant of children's informal relationships at school because they are influenced by the teacher:

'teachers take an active role in promoting positive and healthy relationships at school, they will be promoting children's development and fostering school performance. [ . .. Therefore] teachers should adopt a cooperative mode of teaching, act as social referents for their students' behaviour and avoid negative feedback to aggressive-rejected children to prevent further rejection'. [39] (p. 31)

Several papers discuss race from the peer effect point of view (e.g., McGlothlin and Killen [40]) and suggest that social experiences in school settings and children's intergroup contacts affect their perception of similarity and their sense-making of cross-race friendships. The authors suggest that attending a heterogeneous school has a more positive effect on children's friendships compared to attending a homogeneous school. The effect extends to school resources such as wall posters, bulletin boards and displays of the children's artwork. They found that themes related to diversity were more frequent in heterogeneous compared to homogeneous schools [40] (p. 688). Based on a review of the literature, McGlothlin and Killen state that:

'cross-race friendships have been found to be a significant factor in the reduction of prejudice (... ) Children with friends from different ethnic groups recognize that variation exists across groups as well as within groups, thus reducing outgroup homogeneity attributions. Cross-race friendships also increase sensitivity to the negative impact of discrimination and prejudice'. [40] (p. 683)

Mitchell [41] also deals with the peer effect and the extent to which the classroom shapes prejudicial attitudes. Mitchell shows that individual attitudes are aligned to those of the group, but that this effect 
diminishes after primary school and that 'rather the classroom effect establishes a new baseline level of prejudice in the adolescents in the study when they entered high school' [41] (p. 1528).

Overall, the papers in this category see diversity and heterogeneity as positive for classroom interactions and consider socialisation of pupils with diversity as an asset.

\subsection{Homogeneity versus Heterogeneity}

The debate on the benefits of homogeneity versus the benefits of heterogeneity is relatively balanced (see [42-44] for homogeneity and [45-47] for heterogeneity). Booij et al. [42] suggest that group homogeneity benefits performance and that students gain from tracking by ability level. They pointed that:

'we see that there is no evidence for high-ability groups that the heterogeneity in the group affects students. For low-ability groups, on the other hand, we find that low-ability students are negatively affected by more heterogeneity in the group, while again we find no peer effects for high-ability students. In summary, we find peer effects for low-ability students, but not for high-ability students. Lowability students benefit from being with more able peers but not in very homogenous groups, and they are harmed by heterogeneity unless they are placed in a high-ability group.' [42] (p. 559)

Dang et al. [43] suggest that homogeneity is associated positively to students' self-efficacy, with higher levels of interaction associated to stronger identification with the class. In a study of Turkish students show that the homogeneity of classroom achievement and within school achievement is the most important predictor of students' Programme for International Student Assessment (PISA) mathematics scores [44]. This author considers that the benefits of homogeneity are reflected in students' academic performance, which is a strong argument for segregation.

However, Marotta finds that, although the learning of high achievers might be lower in diverse settings, ability grouping can be detrimental to low achievers and is:

'even more problematic if teachers in low tracks do not adapt their instruction to target the needs of students who struggle academically, leading the gains among high achievers not to be large enough to compensate for the losses of low performing students'. [45] (p. 121)

The study by Cooper et al. [46] on the effects of cooperative, competitive and individual experience on interpersonal attraction among heterogeneous peers, finds that experiences of cooperation promote interpersonal attraction compared to competitive or individual experience, and that competition promotes interpersonal attraction more than individual experiences. Moreover, in contrast to the findings of a positive effect of homogeneity on performance, Winsler and col. find no effect of heterogeneity on student outcomes and show that students in classes with heterogeneous ability benefit from cognitive activation and a supportive climate [47].

The studies in this category focus mainly on the effect of peer heterogeneity/homogeneity in student academic performance and provide mixed results.

\subsection{Gender}

Sex homophily and gender interaction are analysed by Decristan et al. [48] in a longitudinal analysis of sex segregation and gender socialisation in young children. Gender has a direct effect on children; they choose to interact with peers of the same sex and with classmates interested in analogous gender-typed activities; they show that this tendency tends to strengthen over time: 'children became more similar to their interactional partners in levels of engagement in gender-typed activities $(\ldots)$ The more time children spent with peers who engaged in similar levels of gender-typed activities, the more they were exposed to same-sex peers' [48] (p. 935)

The gender interaction analysis in [49] shows that children's spontaneous play groups are more likely to contain a member of the opposite gender if the group is heterogeneous with respect to age 
compared to groups comprising children of the same age. This supports previous findings showing that gender segregation is more frequent among groups of girls than among groups boys and more frequent among four-year-olds compared to three-year-olds.

An epidemiological study of a British high school population, conducted by Conlan et al. [50], found patterns of sex bias and clustering in school peer networks and segregation between boys and girls, with very little observed social communication between them.

The papers in this category show evidence of the process of gender segregation along the educational system. However, their number is too small to allow for the identification of clear effects of school homogeneity versus school heterogeneity in classroom interaction in relation to gender.

\subsection{Disability}

A study conducted in the 1980s, analysing the interactions and relationships between severely handicapped and non-handicapped seventh-grade students, found that cooperative learning compared to individual learning promoted higher levels of interaction and interpersonal attraction between the members of both of these groups of students [51].

A study conducted by Perez Galan [52] found that heterogeneity is fundamental to avoiding social exclusion and pursuing normalisation of special educational needs, learning and knowledge: 'which entail processes of negotiation and reinterpretation of meaning in class, where others' interpretations and contributions, as well as feelings and affection towards each other, are always accepted in contexts of diversification and empathetic support of relevant aspects of the individuals with no discrimination at all' [52] (p. 444)

Again, there are too few papers in this category to identify a trend. However, the above findings are consistent with the idea that heterogeneity promotes tolerance and is necessary for an inclusive society.

\subsection{Age}

The study by Decristan et al. [48] on school homogeneity and classroom interaction is prominent. They analyse social interaction and task behaviour among a class that includes a mix of preschool age children and two separate classes of three-year-olds and four-year-olds. They found differences in goal-directed activities, sustained attention and time spent with peers and away from the teacher for all three groups and that these differences increased for the separate age classes, but not the group that included both three- and four-year-olds, which:

'has important implications for developmental theory and research. This is strong evidence of the important role that the social context plays in children's behavioral development [ ... ]

A phenomenon that may have been assumed originally to be due to the age of the child could also, or instead, be due to the context in which children are observed'. [48] (p. 323-324)

They assume that: 'there could easily be other advantages to MA [mixed age] grouping for the older children (like the diversity of social experience afforded by increased gender and age desegregation or other social climate variables not explored in the present study) that balance or outweigh these findings' [48] (p. 324).

\section{Discussion}

There seems to be a large body of scientific evidence suggesting that social experiences in school settings and children's intergroup contact influence children's perceptions of similarity and their reasoning about cross-age, cross-ability, cross-gender and cross-race friendships. It seems that children attending heterogeneous schools are more positive about friendships than children attending homogeneous schools. Several studies, such as that by Anyon [22], show that class homogeneity and teacher-student interactions are relevant to children's goal setting. Other studies, not reviewed here, have analysed how school choice $[53,54]$ affects classroom diversity and consequent classroom 
interactions, at the teacher-student, family-school and student-student levels [55-57]. The present study focused on student-student and teacher-student interactions.

Our findings show that, although few studies focus on this topic, it has attracted more interest in recent years. The most frequent subtopics are pedagogy, and ethnicity and teachers, and the homogeneity-heterogeneity debate. Gender, disability and age have received less attention. Our results show that, overall, heterogeneity is considered characteristic of modern societies and is reflected in schools. Moreover, heterogeneity in ethnicity, gender, ability, age and social class can benefit students' learning and in socialisation processes. Diversity and heterogeneity are positive for classroom interaction and socialisation with a more diverse society. Despite some of the benefits identified, which derive from homogeneity, they tend to be related to the best-performing schools and students. There is no consensus on segregation in relation to its benefits on achievement. It is considered as detrimental to promotion of tolerance and an inclusive society.

This research has implications for education policy because the degree of school heterogeneity is often the consequence of policies that support freedom of choice for families. Freedom of choice refers to the type of education the family prefers and is often considered more effective in the private system [58-60]. However, the sociology of education argues that education choice is related to social class $[17,61-63]$ and that both dual and triple school systems are related to more choice, but only among more well-resourced families [64-66]. Since a 'choice' with 'tracking' and 'school variability' system threatens cohesion dynamics and social equity, it risks children's learning and education quality and equity [23].

The research in this paper has implications for the research community and suggests that the focus should shift from the advantages of homogeneity based on performance and move to a focus on justice, education equity and the right of all pupils to a good education regardless of their characteristics. It should also focus on the role of education in diversity and equal opportunities.

The research in this paper has some limitations. First, the search terms used to identify the articles included in the analysis are not exhaustive. Further research could include additional search terms to identify similar studies. Moreover, the relatively small number of articles does not allow for further categorisations (such as specific age groups, concrete ethnic groups). Widening the search by including other concepts would provide some insights into these subcategories.

Funding: This research received no external funding.

Conflicts of Interest: The author declares no conflict of interest.

\section{References}

1. Dewey, J. Education as a Social Function. In Democracy and Education; The Free Press: New York, NY, USA, 1916; pp. 10-22.

2. Little, W.; Vyain, S.; Scaramuzzo, G.; Cody-Rydzewski, S.; Griffiths, H.; Strayer, E.; Keirns, N. Introduction to Sociology-1st Canadian Edition; BC Campus: Victoria, BC, Canada, 2014.

3. Giddens, A.; Duneier, M.; Appelbaum, R.P.; Carr, D.S. Introduction to Sociology; Norton: New York, NY, USA, 1991.

4. Bowlby, J. A Secure Base; Routledge: Padstow, Cornwall, UK, 2005. Available online: https://www.routledge. com/A-Secure-Base/Bowlby/p/book/9780415355278 (accessed on 12 November 2020).

5. Vila, I. Familia y escuela: Dos contextos y un solo niño. Aula Innovación Educ. 1995, 4, 72-76.

6. Cebolla-Boado, H.; Radl, J.; Salazar, L. Aprendizaje y ciclo vital. In La Desigualdad de Oportunidades Desde la Educación Preescolar Hasta la Edad Adulta; Fundación La Caixa: Barcelona, Spain, 2014.

7. Javier, M.V.L. Ancheta Arrabal, A. La escuela infantil hoy: La escuela infantil hoy. Perspectivas Internacionales de la Educación y la Atención a la Primera Infancia; Valencia, Spain, 2011. Available online: https://dialnet.unirioja.es/ servlet/articulo? codigo=3838325 (accessed on 18 November 2020).

8. Dreeben, R. the contribution of schooling to the learning of norms. Harv. Educ. Rev. 1967, 37, 211-237. [CrossRef]

9. Ballantine, J.H.; Hammack, F.M. The Sociology of Education; Pearson Higher Ed.: London, UK, 2011.

10. Gracey, H.L. Learning the student role: Kindergarten as academic boot camp. In Schools and Society: A Sociological Approach to Education, 5th ed.; Ballantine, J.H., Spade, J.Z., Eds.; Sage: Newbury Park, CA, USA, 2014; pp. 147-152. 
11. Galán, R.P. Los nuevos retos del aprendizaje social en niños con necesidades educativas especiales: El aprendizaje en comunidad o la comunidad de aprendizaje en el aula. Rev. Educ. 2009, 348, 443-464.

12. Levin, B. Approaches to equity in policy for lifelong learning. In Education and Training Policy Division, OECD; OECD: Paris, France, 2003.

13. Beltrán, J.; Montané, A.; Gabaldón-Estevan, D. Higher education in Spain: Framework for equity. In Equity in Higher Education. A Global Perspective; Paivandi, S., Joshi, K.M., Eds.; Studera Press: New Delhi, India, 2016; pp. 149-185.

14. Põder, K.; Kerem, K.; Lauri, T. Efficiency and Equity within European Education Systems and School Choice Policy: Bridging qualitative and quantitative approaches. J. Sch. Choice 2013, 7, 1-36. [CrossRef]

15. Council of Europe Commissioner for Human Rights School Segregation Still Deprives Many Children of Quality Education. Position Paper. 2017. Available online: https://www.coe.int/en/web/commissioner/-/ school-segregation-still-deprives-many-children-of-quality-education (accessed on 24 August 2020).

16. Ridao-Cano, C.; Bodewig, C. Growing United: Upgrading Europe's Convergence Machine: Overview (English); World Bank Group: Washington, DC, USA, 2018. Available online: http://documents.worldbank.org/curated/ en/852701520358672738/Overview (accessed on 24 August 2020).

17. Gabaldón-Estevan, D. Educación y Atención a la Primera Infancia en la Ciudad de Valencia; Editorial Universitat Politècnica de València: Valencia, Spain, 2016.

18. Colom-Ortiz, F.; Gabaldón-Estevan, D. Recursos educativos y primera infancia: Privatización de la educación infantil de primer ciclo en la ciudad de Valencia. RASE 2016, 9, 277-298.

19. Fernández-Esquinas, F. Elección de escuela: Efectos sociales y dilemas en el sistema educativo público en Andalucía. Rev. Educ. 2004, 334, 377-390.

20. Fernández-Mellizo, M.; Martínez-García, J.S. Inequality of educational opportunities: School failure trends in Spain (1977-2012). Int. Stud. Sociol. Educ. 2017, 26, 267-287. [CrossRef]

21. Bukhari, P.; Randall, E.V. Exit and entry: Why parents in Utah left public schools and chose private schools. J. Sch. Choice 2009, 3, 242-270. [CrossRef]

22. Anyon, J. Social class and the hidden curriculum of work. J. Educ. 1980, 162, 67-92. [CrossRef]

23. Murillo, F.J.; Martínez-Garrido, C. Magnitud de la segregación escolar por nivel socioeconómico en España y sus Comunidades Autónomas y comparación con los países de la Unión Europea. Rev. Sociol. Educ. 2018, 11, 37-58. [CrossRef]

24. Moher, D.; Liberati, A.; Tetzlaff, J.; Altman, D.G. The PRISMA Group Preferred reporting items for systematic reviews and meta-analyses: The PRISMA statement. PLoS Med. 2009, 6, e1000097. [CrossRef] [PubMed]

25. Levine-Clark, M.; Gil, E. A comparative analysis of social sciences citation tools. In Online Information Review; Emerald Group Publishing Limited: Bingley, UK, 2009.

26. Falk, D.R.; Johnson, D.W. The effects of perspective-taking and egocentrism on problem solving in heterogeneous and homogeneous groups. J. Soc. Psychol. 1977, 102, 63-72. [CrossRef]

27. Johnson, D.W.; Johnson, R.T.; Scott, L. The effects of cooperative and individualized instruction on student attitudes and achievement. J. Soc. Psychol. 1978, 104, 207-216. [CrossRef]

28. Johnson, D.W.; Maruyama, G.; Johnson, R.; Nelson, D.; Skon, L. Effects of cooperative, competitive, and individualistic goal structures on achievement: A meta-analysis. Psychol. Bull. 1981, 89, 47. [CrossRef]

29. Waldripl, B.G.; Fisher, D.L. A culturally sensitive learning environment instrument for use in science classrooms: Development and validation. In Proceedings of the 21st Annual Conference of the Western Australian Science Education Association, Mount Lawley, Australia, 29 November 1996; Volume 188, p. 188.

30. Peralta, N.S.; Roselli, N.D.; Borgobello, A. El conflicto sociocognitivo como instrumento de aprendizaje en contextos colaborativos. Interdisciplinaria 2012, 29, 325-338. [CrossRef]

31. Kärner, T.; Warwas, J. Functional relevance of students' prior knowledge and situational uncertainty during verbal interactions in vocational classrooms: Evidence from a mixed-methods study. Empir. Res. Vocat. Educ. Train. 2015, 7, 11. [CrossRef]

32. Barrio-Parra, F.; Izquierdo-Díaz, M.; Bolonio, D.; Sánchez-Palencia, Y.; Fernández-GutiérrezdelAlamo, L.; Mazadiego, L. Flip Teaching vs Collaborative learning to deal with Heterogeneity in large groups of students. In Proceedings of the 13th International Technology, Education and Development Conference, Valencia, Spain, 11-13 March 2019; pp. 212-218.

33. Chen, H.; Zeng, Q.; Peng, Z. Creating the Recognition of Heterogeneity in Circle Rituals: An Ethnographic Study in a German Primary School. Sage Open 2020, 10, 2158244019899440. [CrossRef] 
34. Mooij, T. Secondary school teachers' personal and school characteristics, experience of violence and perceived violence motives. Teach. Teach. Theory Pract. 2011, 17, 227-253. [CrossRef]

35. Riegel, C. Dealing with diversity and social heterogeneity: Ambivalences, challenges and pitfalls for pedagogical activity. In International Handbook of Migration, Minorities and Education; Springer: Dordrecht, The Netherlands, 2012; pp. 331-347.

36. García-Sánchez, I.M. The everyday politics of "cultural citizenship" among North African immigrant school children in Spain. Lang. Commun. 2013, 33, 481-499. [CrossRef]

37. Yates, T.M.; Marcelo, A.K. Through race-colored glasses: Preschoolers' pretend play and teachers' ratings of preschooler adjustment. Early Child. Res. Q. 2014, 29, 1-11. [CrossRef]

38. Penney, J. Racial interaction effects and student achievement. Educ. Financ. Policy 2017, 12, 447-467. [CrossRef]

39. Muñoz-Hurtado, J. The Role of Teachers on Students'peer Groups Relations: A Review on Their Influence on School Engagement and Academic Achievement. Limite 2018, 13, 30-43.

40. McGlothlin, H.; Killen, M. Children's perceptions of intergroup and intragroup similarity and the role of social experience. J. Appl. Dev. Psychol. 2005, 26, 680-698. [CrossRef]

41. Mitchell, J. Prejudice in the classroom: A longitudinal analysis of anti-immigrant attitudes. Ethn. Racial Stud. 2019, 42, 1514-1533. [CrossRef]

42. Booij, A.S.; Leuven, E.; Oosterbeek, H. Ability peer effects in university: Evidence from a randomized experiment. Rev. Econ. Stud. 2017, 84, 547-578. [CrossRef]

43. Dang, J.; Liu, L.; Du, Y. Benefits of a highly entitative class for adolescents' psychological well-being in school. Sch. Ment. Health 2019, 11, 766-776. [CrossRef]

44. Uysal, S.; Banoglu, K. Hogging the Middle Lane: How Student Performance Heterogeneity Leads Turkish Schools to Fail in PISA? Cypriot J. Educ. Sci. 2018, 13, 448-460. [CrossRef]

45. Marotta, L. Peer effects in early schooling: Evidence from Brazilian primary schools. Int. J. Educ. Res. 2017, 82, 110-123. [CrossRef]

46. Cooper, L.; Johnson, D.W.; Johnson, R.; Wilderson, F. Effects of cooperative, competitive, and individualistic experiences on interpersonal attraction among heterogeneous peers. J. Soc. Psychol. 1980, 111, $243-252$.

47. Winsler, A.; Caverly, S.L.; Willson-Quayle, A.; Carlton, M.P.; Howell, C.; Long, G.N. The social and behavioral ecology of mixed-age and same-age preschool classrooms: A natural experiment. J. Appl. Dev. Psychol. 2002, 23, 305-330. [CrossRef]

48. Decristan, J.; Fauth, B.; Kunter, M.; Büttner, G.; Klieme, E. The interplay between class heterogeneity and teaching quality in primary school. Int. J. Educ. Res. 2017, 86, 109-121. [CrossRef]

49. Martin, C.L.; Kornienko, O.; Schaefer, D.R.; Hanish, L.D.; Fabes, R.A.; Goble, P. The Role of Sex of Peers and Gender-Typed Activities in Young Children's Peer Affiliative Networks: A Longitudinal Analysis of Selection and Influence. Child Dev. 2013, 84, 921-937. [CrossRef] [PubMed]

50. Conlan, A.J.; Eames, K.T.; Gage, J.A.; von Kirchbach, J.C.; Ross, J.V.; Saenz, R.A.; Gog, J.R. Measuring social networks in British primary schools through scientific engagement. Proc. R. Soc. B Biol. Sci. 2011, 278, 1467-1475. [CrossRef] [PubMed]

51. Johnson, R.T. Integrating severely adaptively handicapped seventh-grade students into constructive relationships with nonhandicapped peers in science class. Am. J. Ment. Defic. 1983, 87, 611-618. [PubMed]

52. Perez Galan, R. The new challenges of social learning for children with special educational needs. Learning in the community, or the community of learning in the classroom. Rev. Educ. 2009, 348, 271-272.

53. Hawley, W. The false premises and false promises of the movement to privatize public education. Teach. Coll. Rec. 1995, 96, 735-742.

54. Teese, R. Curriculum Hierarchy, Private Schooling, and the Segmentation of Australian Secondary Education, 1947-1985. Br. J. Sociol. Educ. 1998, 19, 401-417. [CrossRef]

55. Ryan, A.M. Peer groups as a context for the socialization of adolescents' motivation, engagement, and achievement in school. Educ. Psychol. 2000, 35, 101-111. [CrossRef]

56. Ryan, A.M. The peer group as a context for the development of young adolescent motivation and achievement. Child Dev. 2001, 72, 1135-1150. [CrossRef]

57. Kiuru, N.; Aunola, K.; Nurmi, J.E.; Leskinen, E.; Salmela-Aro, K. Peer group influence and selection in adolescents' school burnout: A longitudinal study. Merrill Palmer Q. 2008, 54, 23-55. [CrossRef]

58. Granell Pérez, R.G.; Fuenmayor Fernández, A. La calidad de la educación infantil: La opinión de los padres. In VIII Encuentro de Economía Pública; VIII Encuentro de Economía Pública: Cáceres, Spain, 2001; p. 27. 
59. Bosetti, L.; Pyryt, M.C. Parental motivation in school choice: Seeking the competitive edge. J. Sch. Choice 2007, 1, 89-108. [CrossRef]

60. English, R. Selling education through "culture": Responses to the market by new, non-government schools. Aust. Educ. Res. 2009, 36, 89-104. [CrossRef]

61. Hatcher, R. Class differentiation in education: Rational choices? Br. J. Sociol. Educ. 1998, 19, 5-24. [CrossRef]

62. Rich, P.M.; Jennings, J.L. Choice, Information, and Constrained Options School Transfers in a Stratified Educational System. Am. Sociol. Rev. 2015, 80, 1069-1098. [CrossRef]

63. Vincent, C.; Maxwell, C. Parenting priorities and pressures: Furthering understanding of 'concerted cultivation'. Discourse Stud. Cult. Politics Educ. 2016, 37, 269-281. [CrossRef]

64. Mancebón, M.J.; Pérez-Ximénez, D. Conciertos educativos y selección académica y social del alumnado. Hacienda Pública Española 2007, 180, 125-154.

65. Fernández-Enguita, M. Escuela pública y privada en España: La segregación rampante. RASE 2008, 1, 2.

66. Fernández-Llera, R.; Muñiz-Pérez, M. Colegios concertados y selección de escuela en España: Un círculo vicioso. Presup. Y Gasto Público 2012, 67, 97-118.

Publisher's Note: MDPI stays neutral with regard to jurisdictional claims in published maps and institutional affiliations.

(C) 2020 by the author. Licensee MDPI, Basel, Switzerland. This article is an open access article distributed under the terms and conditions of the Creative Commons Attribution (CC BY) license (http://creativecommons.org/licenses/by/4.0/). 